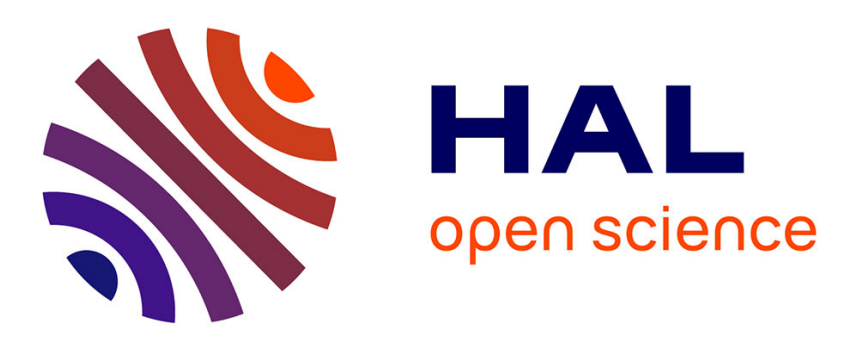

\title{
Genetic and aquaculture performance differentiation among wild allopatric populations of European perch (Percidae, Perca fluviatilis)
}

T. Vanina, R. Gebauer, L. Toomey, V. Stejskal, M. Rutegwa, J. Kouřil, M. Bláha, T. Lecocq

\section{To cite this version:}

T. Vanina, R. Gebauer, L. Toomey, V. Stejskal, M. Rutegwa, et al.. Genetic and aquaculture performance differentiation among wild allopatric populations of European perch (Percidae, Perca fluviatilis). Aquaculture, 2019, 503, pp.139-145. 10.1016/j.aquaculture.2018.12.071 . hal-01972549

\section{HAL Id: hal-01972549 \\ https://hal.univ-lorraine.fr/hal-01972549}

Submitted on 8 Mar 2019

HAL is a multi-disciplinary open access archive for the deposit and dissemination of scientific research documents, whether they are published or not. The documents may come from teaching and research institutions in France or abroad, or from public or private research centers.
L'archive ouverte pluridisciplinaire HAL, est destinée au dépôt et à la diffusion de documents scientifiques de niveau recherche, publiés ou non, émanant des établissements d'enseignement et de recherche français ou étrangers, des laboratoires publics ou privés. 


\title{
Genetic and aquaculture performance differentiation among wild allopatric populations of European perch (Percidae, Perca fluviatilis)
}

\author{
T. Vanina ${ }^{\mathrm{a}, *}$, R. Gebauer ${ }^{\mathrm{a}}$, L. Toomey ${ }^{\mathrm{b}}$, V. Stejskal $^{\mathrm{a}}$, M. Rutegwa $^{\mathrm{a}}$, J. Kouřil ${ }^{\mathrm{a}}$, M. Bláha ${ }^{\mathrm{a}}$, T. Lecocq ${ }^{\mathrm{b}}$ \\ ${ }^{\text {a }}$ University of South Bohemia in Ceske Budejovice, Faculty of Fisheries and Protection of Waters, South Bohemian Research Centre of Aquaculture and Biodiversity of \\ Hydrocenoses, Zátiší 728/II, Vodñany 38925, Czech Republic \\ ${ }^{\mathrm{b}}$ Université de Lorraine, INRA, URAFPA, F-54000 Nancy, France
}

\section{A R T I C L E I N F O}

\section{Keywords:}

Aquaculture

Genetic differentiation

Phenotypic plasticity

Perca fluviatilis

\begin{abstract}
A B S T R A C T
Present research suggests that phenotypic variations and consequent potential differences in suitability for commercial culture are more likely to occur among genetically diverse populations. We investigated diversity in traits important to aquaculture and assessed genetic differentiation based on four mitochondrial markers in three European populations of Perca fluviatilis. Using a transplant approach to standardize conditions and minimize environmental effects on phenotype expression, we compared survival, cannibalism, growth rate, growth heterogeneity, and specific growth rate of the populations to assess whether difference in aquaculture performance (i.e. expression of phenotypical traits that facilitate the rearing of fish and impact the productivity of the farming) is more likely between genetically differentiated populations than between genetically similar populations. We found key traits of performance to differ among allopatric populations, suggesting value in considering geographic source of broodstock. The largest aquaculture performance disparities were observed among genetically differentiated populations. Some lesser differences were observed between allopatric genetically similar populations, possibly the consequence of pre-collection environment, or transgenerational effects.
\end{abstract}

\section{Introduction}

Aquaculture is one of the fastest growing food-producing sectors (FAO, 2016), with current fish production involving a small number of species (Teletchea and Fontaine, 2014). This low diversity leads to negative consequences with respect to (1) wild environments (non-native species invasion triggered by translocations of the few produced species out of their natural range for production or trade purpose; (Garibaldi and Bartley, 1998), (2) food security via high epizooty hazard for key species in the human food supply (Godoy et al., 2008), and (3) economic prospects due to low potential to adapt to changes in environment/consumer demand (Fontaine et al., 2009). The diversification of fish production to increase aquaculture sustainability (Fontaine et al., 2009) is an emerging trend including the development of European perch (Perca fluviatilis L.) culture (Kestemont et al., 2015).

The European perch is a widespread freshwater predatory species (Stepien and Haponski, 2015). This is a polytypic species that displays geographic differentiation in genetic (Nesbø et al., 1999) and phenotypic traits (Mandiki et al., 2004; Pimakhin and Žák, 2014) throughout its distribution range. Its high market value along with increasing consumer demand make it commercially important in some European countries (i.e. especially in France and Switzerland) where over $500 \mathrm{t}$ are produced annually (Toner, 2015; FAO, 2016). Nowadays, most of the production relies on fish bred in intensive aquaculture systems (i.e. re-circulating aquaculture systems, RAS) and harvested at $80-100 \mathrm{~g}$ (Toner, 2015). The RAS production development began early in the large scale $P$. fluviatilis aquaculture since this farming system allows improving (i) efficiency and profitability of culture by reducing time to marketable weight, (ii) water consumption, (iii) waste management, (iv) disease control, and (v) stable temperature maintenance (Żarski et al., 2017). However, production of European perch still fails to meet market demands (Kestemont et al., 2015). Indeed, several obstacles in the life cycle and breeding performance of the current European perch stock hinder culture development: asynchronous spawning, high larval mortality, low growth rate, high growth heterogeneity, and high rates of cannibalism among larvae (Brabrand, 1995; Tamazouzt et al., 2000; Baras et al., 2003; Policar et al., 2008; Rougeot and Mélard, 2008).

Several studies have determined that presence of traits desirable for aquaculture can vary between geographically distinct wild populations, i.e., in Coho salmon (Oncorhynchus kisutch) (Rosenau and McPhail, 1987) and striped bass (Morone saxatilis) (Brown, 1994; Conover et al., 1997; Brown et al., 1998). Growth, survival, larval malformation, and

\footnotetext{
* Corresponding author.

E-mail address: tvanina@frov.jcu.cz (T. Vanina).
} 
cannibalism (so-called zootechnical traits) have also been shown to differ among wild allopatric populations of European perch (Mandiki et al., 2004; Pimakhin and Žák, 2014). The geographic differentiation of key traits for aquaculture means that choosing wild perch from areas displaying optimum survival, growth, and cannibalism rates in aquaculture conditions may be important for the establishment or enhancement of fish farming broodstock, as was shown for $P$. flavescens (Rosauer et al., 2011). Since known geographic differentiation of $P$. fluviatilis traits included features involved in current bottlenecks of its aquaculture, this may ultimately help to overcome current challenges in European perch aquaculture.

Although some hypotheses have been put forward to explain geographic differentiations of phenotypic traits desirable for aquaculture (e.g., Mandiki et al., 2004, Rosauer et al., 2011). Population differences in specific traits can be shaped by genetic differentiation fostered by gene flow reduction among separated or isolated populations or by phenotypic plasticity, the capacity of a genotype to vary in phenotype depending on environmental or developmental conditions (Pigliucci et al., 2006), or their combination (Avise, 2000; DeWitt and Scheiner, 2004; Bergek and Björklund, 2009). Earlier studies comparing survival, cannibalism, and growth rates of allopatric $P$. fluviatilis populations have employed an experimental transplant approach (Mandiki et al., 2004; Pimakhin and Žák, 2014), which reduces environmental effects. Since allopatric populations are placed in the same environment, one would expect phenotypic variation and potential consequent differences in aquaculture performance to occur among genetically differentiated populations (see genetic differentiation in European populations in Nesbø et al., 1999). However, previous studies did not assess the genetic differentiation between studied populations and investigated only early life stages derived from eggs collected from the wild. Since environmental impact on gene expression and resulting phenotypes may or may not be consistent throughout life and can also affect succeeding generations, it is not known if observed differences among populations are genetically- or environmentally-induced.

In this study, we aim at (i) highlighting the geographic differentiation in keys traits for aquaculture and (ii) investigating the genetic basis of this potential differentiation in $P$. fluviatilis. To this end, we develop a comparison of survival, growth parameters, and cannibalism in three allopatric European populations through a transplant experimental design, placing each population in the same standardized conditions, coupled with a genetic assessment based on four mitochondrial markers.

\section{Materials and methods}

\subsection{Wild fish stock and initial egg assessment}

Egg ribbons of three wild allopatric fish populations were collected from three localities in different drainage basins (Table 1) corresponding to areas where occur genetically different populations according to Nesbø et al. (1999). The egg ribbons were sampled at the beginning of the European perch spawning season (i.e. this beginning was determined by collaborators' population monitoring; from the end of April and beginning of May). We transported egg ribbons by car to the experimental facility of the Faculty of Fisheries and Protection of Waters, South Bohemia University. Eggs were held in oxygenated polyethylene bags (filled $1 / 3$ of water, $2 / 3$ of oxygen, t-16 $\pm 1{ }^{\circ} \mathrm{C}$ ) placed in a thermo box: 10 ribbons from Poland, 11 ribbons from the Czech Republic, and 12 ribbons from Slovakia. After the transportation, we determined the developmental advancement of ribbons by randomly choosing 150 eggs per population, photographing them, and comparing them to references from Żarski et al. (2011). Polish and Slovakian populations were on 6 days post-fertilization (dpf) while the Czech population was on approximately $8 \mathrm{dpf}$. At the facility, bags were placed into separate $200 \mathrm{~L}$ hatching tanks filled with dechlorinated tap water $\left(17^{\circ} \mathrm{C} \pm 0.5, \mathrm{pH}=7 \pm 0.5\right.$, oxygen $\left.{ }^{>} 90 \%\right)$ for temperature acclimatization. When temperature in the bag and hatching tank equalized, egg ribbons were placed onto the net bottom of hatching cages Żarski et al. (2017) until three days post-hatching (dph). During this period, $50 \%$ of water volume was replaced daily. Water temperature, $\mathrm{pH}$, and oxygen saturation were maintained at $17 \pm 0.8^{\circ} \mathrm{C}$, $7 \pm 0.5$, and $>90 \%$, respectively.

After temperature acclimatization, 150 randomly chosen eggs per population were sampled to assess fertilization rate according to (Křištan et al., 2012). At the eyed stage, the inner diameter, not including the gelatinous coat, of 100 randomly sampled eggs was measured following Żarski et al. (2011) using a Leica Z6-APO scope (Leica Microsystems, Switzerland). The eggs from Poland (PL), Czech Republic (CZ), and Slovakia (SK) hatched on 2, 9, and 12 May 2017, respectively.

\subsection{Pre-experiment rearing protocol}

All populations were reared in the same conditions. At $3 \mathrm{dph}$, larvae were transferred into an RAS. We mixed larvae from 10 ribbons per each population in this system. The light grey tanks sized $22.5 \times 30 \times 89 \mathrm{~cm}, 60 \mathrm{~L}$ with water flow-through averaging $1 \mathrm{~L} / \mathrm{min}$ in each tank till 31th $\mathrm{DPH}\left(17 \pm 0.8^{\circ} \mathrm{C}, \mathrm{pH}=7 \pm 0.5\right.$, oxygen $\left.{ }^{>} 90 \%\right)$. We used a density of 67 specimens $\mathrm{L}^{-1}$. The feeding was initiated 3 days after hatching with Artemia nauplii up to day 24 (Tamazouzt et al., 2000; Jentoft et al., 2006). During the first seven days of feeding, larvae were fed manually at $2 \mathrm{~h}$ intervals from $08.00-18.00 \mathrm{~h}$ with micro-Artemia nauplii of $350-380 \mu \mathrm{m}$ (Ocean Nutrition) in ration 700 nauplii per larvae. Micro-Artemia nauplii was subsequently replaced with Artemia nauplii with hatching ${ }^{>} 260,000$ nauplii $\mathrm{g}^{-1}$ (Ocean $\mathrm{Nu}$ trition) at rations for the second week $35 \%$ of fish biomass and $10 \%$ for the last third week, respectively (Kestemont et al., 2015). At $21 \mathrm{dph}$, Artemia nauplii were progressively replaced with commercial pelleted BioMar Larviva Pro Wean 100 (Nersac, France) over the course of four days, manually fed at $2 \mathrm{~h}$ intervals from $08: 00-18: 00 \mathrm{~h}$ with a daily ration for the first day $10 \%$ Artemia nauplii of fish biomass $+2 \%$ of compound feed, for the second day 5\% Artemia nauplii of fish biomass $+30 \%$ of compound feed, for the third day 5\% Artemia nauplii of fish biomass $+60 \%$ of compound feed and $100 \%$ of compound feed on the 24 dph (Kestemont and Mélard, 2000). From 25 dph juveniles were fed only commercial pellets with the size of pellets which progressively increased according to mean body weight (in ration $0,01 \mathrm{~g}-9,3 \%$; $0,22 \mathrm{~g}-7,4 \%$; 0,73g - 5, 1\%; from 1,56g - 4.5\%) (Fiogbé and Kestemont, 2003). Dead larvae were removed daily. After $3 \mathrm{dph}$ the temperature was gradually increased from $17^{\circ} \mathrm{C}$ to $23^{\circ} \mathrm{C}\left(+1{ }^{\circ} \mathrm{C}\right.$ per day) and kept stable. Temperature, oxygen saturation, and $\mathrm{pH}$ were measured twice daily in the pre-experimental period with a multimeter (Hach Lange HQ40d, Germany). The light intensity ranged 200-250 lx at the water surface. The photoperiod was constant at $12 \mathrm{~L}$ : $12 \mathrm{D}$.

Table 1

Sampling sites of European perch populations.

\begin{tabular}{lllll}
\hline Country & Locality & Habitat & Basin & Latitude(N)/Longitude (E) WGS84 \\
\hline Poland & Stary Dwór Lake & Small lake & Baltic Sea & $53^{\circ} 44^{\prime} 51.6^{\prime \prime} \mathrm{N} 20^{\circ} 27^{\prime} 11.8^{\prime \prime} \mathrm{E}$ \\
Czech Republic & Nové Hrady & pond & North Sea & $48^{\circ} 47^{\prime} 33.8^{\prime \prime} \mathrm{N} 14^{\circ} 48^{\prime} 32.3^{\prime \prime} \mathrm{E}$ \\
Slovakia & River Váh & River & Black Sea & $49^{\circ} 07^{\prime} 29.7^{\prime \prime} \mathrm{N} 18^{\circ} 27^{\prime} 26.2^{\prime \prime} \mathrm{E}$ \\
\hline
\end{tabular}




\subsection{Experimental rearing protocol}

Prior to the experiment (i.e. after pre-experiment rearing), the initial body weight and mortality rate were assessed at 30th day: (1) initial body weight: $0.11 \pm 0.02$ for Slovakians, $0.13 \pm 0.02$ for Czechs, and $0.04 \pm 0.01$ for Polishes; (2) mortality rate: 75\%; 62.5\%; $55 \%$, respectively. The experiment was initiated at $31 \mathrm{dph}$ with feedtrained juveniles, a time when digestive enzymes are expected to be fully developed (Cuvier-Péres and Kestemont, 2001) and mortality associated with feed changes declined (Kestemont et al., 1996; Ljunggren et al., 2003). Juveniles were redistributed into $60 \mathrm{~L}$ light rectangular grey tanks size $22.5 \times 30 \times 89$ with water flow-through of $2 \mathrm{~L} / \mathrm{min}$ in each tank (150 specimens per tank; 2.5 specimens $\mathrm{L}^{-1}$ ) (Mélard et al., $1996)$ in triplicate RAS ( $4000 \mathrm{~L})$ with dechlorinated tap water. The rearing experiment lasted 84 days, from the 31 to $115 \mathrm{dph}$. Dead fish were immediately removed from the tanks and numbers recorded daily. Juveniles were fed manually at $2 \mathrm{~h}$ intervals from 08:00-18:00 $\mathrm{h}$ with a daily ration (Fiogbé and Kestemont, 2003). Concentration of oxygen, $\mathrm{pH}$, and temperature were monitored twice daily. Ammonium and nitrite concentrations were recorded twice weekly. Dissolved oxygen was maintained above $90 \%$ and $\mathrm{pH}$ at $7 \pm 0.5$. Concentrations of ammonium were $0.05 \pm 0.01 \mathrm{mg} \mathrm{L}^{-1}$, while nitrites were $0.05 \pm 0.02 \mathrm{mg} \mathrm{L}^{-1}$ measured with portable spectrophotometer (DR 2800, Hach Company, USA). The light intensity ranged 200-250 lx at the water surface. The photoperiod was constant at $12 \mathrm{~L}$ : $12 \mathrm{D}$.

\subsection{Assessment of aquaculture performance of fish populations}

\subsubsection{Measurements}

All fish were weighed and measured at 31, 59, 87, and $115 \mathrm{dph}$ for body weight, specific growth, and growth heterogeneity. At each sampling date, 15 specimens per tank (45 per population) were anaesthetized using clove oil solution at $0.015 \mathrm{mg} \mathrm{L}^{-1}$ and weighed (OHAUS Explorer EX224M, NJ, USA) to the nearest $0.1 \mathrm{mg}$. Specific growth rate (SGR, \%/day) was calculated by $S G R=100 *\left(\ln _{2^{-}}\right.$ $\left.\ln \mathrm{W}_{1}\right) * \Delta \mathrm{T}^{-1}$, in which $\mathrm{W} 1$ and $\mathrm{W} 2$ are the initial and final mean body weight, and $\Delta \mathrm{T}$ is the time interval between samplings in days. Growth heterogeneity $(\mathrm{GH})$ was calculated from $\mathrm{CV}_{\mathrm{FBW}} / \mathrm{CV}_{\mathrm{IBW}}$, where $\mathrm{CV}$ is the coefficient of variation (100*SD/mean) and IBW and FBW are the initial and final body weight.

Mortality rate (MR, \%) was calculated from number of dead fish as $D_{f}{ }^{*} 100 / N i$, in which $D_{f}$ is number of dead fish and $N_{i}$ is the number of initial stocked fish per tank. This rate was calculated for four time periods (31-59 dph, $59-87 \mathrm{dph}, 87-115 \mathrm{dph}$, and $31-115 \mathrm{dph}$ ). The number of dead fishes was recorded daily.

Cannibalism rates (i.e. cannibalism type II) were recorded at the end of experiment at $115 \mathrm{dph}$. Cannibalism rate (CR, \%) was calculated as $\mathrm{CR}=\left(\left(\mathrm{N}_{\mathrm{i}}-\mathrm{N}_{\mathrm{d}}-\mathrm{N}_{\mathrm{f}}\right) / \mathrm{Ni}\right) * 100$, where $\mathrm{Ni}$ and $\mathrm{Nf}$ are the initial and final numbers of fish, respectively, and $\mathrm{N}_{\mathrm{d}}$ is the number of dead fish counted during the experiment (Kestemont et al., 2003; Mandiki et al., 2004; Ljubobratović et al., 2015).

\subsubsection{Statistical analyses}

Statistical analyses compared the mean values of each factor among the tree fish populations (i.e. using populations as statistical units). Since each group sample was not drawn from a normally distributed population according to the Shapiro-Wilk test, the assumptions for oneway analysis of variance were not met, and the Kruskal-Wallis test by rank was used to assess differences in growth rate, growth heterogeneity, mortality, and cannibalism. When significant differences were detected, Dunn's multiple comparison test was used to identify specific population differences. Statistical analyses were conducted in R v. 3.4.4 (R Development Core Team, 2018).

\subsection{Assessment of genetic differentiation among fish populations}

To estimate genetic differentiation, fin clips were collected from 15 perch of each population and stored in pure ethanol (99\%). The DNA extraction used a commercial E.Z.N.A. Tissue DNA kit (MachereyNagel, Germany). Fragments of four mitochondrial regions, cytochrome $b$ (Cytb), D-loop of control region (D-loop), 16S rRNA (16S), and cytochrome oxidase I (COI) were amplified using primers L14724F/ H15918R (Irwin et al., 1991), HV2/CSBD (Nesbø et al., 1998), 16Sar/ 16Sbr (Palumbi, 1996), and jgLCO1490/jgHCO2198 (Vrijenhoek, 1994), respectively. These DNA regions are commonly used for determining genetic differences at the intraspecific level (Lecocq et al., 2013) including in European perch (Nesbø et al., 1999). The conditions of the polymerase chain reaction (PCR) were 10 pmol primers, PPP MasterMix (Top Bio), DNA, and distilled water. An initialization step of $5 \mathrm{~min}$ at $95^{\circ} \mathrm{C}$ was followed by 38 cycles of denaturation at $94^{\circ} \mathrm{C}$ for $40 \mathrm{~s}$; $50 \mathrm{~s}$ annealing at $55.8^{\circ} \mathrm{C}$ for $16 \mathrm{~S}, 49^{\circ} \mathrm{C}$ for COI, and $55^{\circ} \mathrm{C}$ for Cytb and D-loop; and 1-minuts extension at $72{ }^{\circ} \mathrm{C}$ plus a 10 -minuts final extension at $72{ }^{\circ} \mathrm{C}$. The PCR products were purified with the E.Z.N.A Gel extraction kit (Macherey-Nagel, Germany) following manufacturer's protocol. The products were sequenced by Macrogen Europe (Amsterdam, Netherlands) on a 3730XL (Applied Biosystems) using primers H15918R, CSBD, 16Sbr, and jgLCO1490.

Nucleotide sequences were manually checked using GENEIOUS 10.1.3 (Kearse et al., 2012). There was no uncertainty in the consensus sequences. For coding genes (COI and Cytb), translation to proteins using the vertebrate mitochondrial DNA genetic code was performed on Mesquite 3.31 (Maddison and Maddison, 2015) to verify that there was no stop codon in coding regions. The fish origin of each sequence was checked with BLAST (https://blast.ncbi.nlm.nih.gov/Blast.cgi). The unique haplotypes found were deposited in GenBank (Table S1).

The alignments were conducted in MAFFT v. 6.0 using FFT-NS-2 algorithm default parameters (Katoh et al., 2017). The four markers were concatenated within a single alignment for the genetic differentiation analyses using Mesquite 3.31. A concatenated haplotype map for each population was created with QGIS software 2.18.3 (https:// qgis.org/en/site/). Analysis of molecular variance (AMOVA, 100,000 permutations) based on allele frequency and estimate of the fixation index $\mathrm{F}_{\mathrm{ST}}$ and pairwise $\mathrm{F}_{\mathrm{ST}}$ were calculated in Arlequin v. 3.5 (Excoffier et al., 2005) with 10,000 random permutations.

\section{Results}

\subsection{Egg assessment}

Fertilization rates of the CZ, SK, and PL populations were $80 \pm 2.3 \%, 90 \pm 4.2 \%$, and $88 \pm 4.1 \%$, respectively. Egg diameter $(\mathrm{mm})$ differed significantly among populations tested (Kruskal-Wallis, $P<.01)$ with mean \pm SD of $1.89 \pm 0.1,1.77 \pm 0.07$, and $1.69 \pm 0.08$ for SK, CZ, and PL populations, respectively.

\subsection{Aquaculture performance}

At $31 \mathrm{dph}$, initial body weight differed significantly among populations (Kruskal-Wallis test, $P<.01$, Table 2). At 59 and $87 \mathrm{dph}$, SK and PL populations showed significantly lower body weight than $\mathrm{CZ}$ (Kruskal-Wallis test, $P<.01$, Table 2). At $115 \mathrm{dph}$, the CZ population showed significantly higher body weight than SK and PL populations.

Throughout the experiment, the SGR was significantly higher in the PL population at most sampling times (Table 2 ). The $\mathrm{CZ}$ population did not differ from SK population at $115 \mathrm{dph}$. (Table 2).

Mortality rates of the populations were similar at most sampling times (Table 2). Kruskal-Wallis test $P$-values 0.05 ( 31 to $59 \mathrm{dph}$ ), 0.19 ( 59 to $87 \mathrm{dph}$ ), $<0.05$ ( 87 to $115 \mathrm{dph}$; (pairwise results Table 2), and 0.24 (31 to $115 \mathrm{dph}$ ). There was no significant difference in survival among the populations throughout the study period (Table 2). 
Table 2

Body weight, specific growth rate, mortality rate, growth heterogeneity, and cannibalism rate (mean \pm standard deviation) of tree populations of European perch juveniles at 31, 59, 87, and $115 \mathrm{dph}$. Different superscripts within a row indicates significant difference. $\quad \mathrm{SK}=$ Slovakia, $\quad \mathrm{CZ}=\mathrm{Czech}$ Republic, $\mathrm{PL}=$ Poland.

\begin{tabular}{llll}
\hline & SK & CZ & PL \\
\hline Body weight (g) & & & \\
31 dph & $0.11 \pm 0.02^{\mathrm{b}}$ & $0.13 \pm 0.02^{\mathrm{c}}$ & $0.04 \pm 0.01^{\mathrm{a}}$ \\
59 dph & $0.38 \pm 0.04^{\mathrm{a}}$ & $0.60 \pm 0.07^{\mathrm{b}}$ & $0.30 \pm 0.03^{\mathrm{a}}$ \\
87 dph & $2.22 \pm 0.22^{\mathrm{a}}$ & $4.12 \pm 0.40^{\mathrm{c}}$ & $3.07 \pm 0.33^{\mathrm{b}}$ \\
115 dph & $5.98 \pm 0.46^{\mathrm{a}}$ & $8.95 \pm 3.14^{\mathrm{b}}$ & $6.70 \pm 0.46^{\mathrm{a}}$ \\
Specific growth rate (\% & & & \\
day ${ }^{-1}$ ) & & & \\
31-59 dph & $4.29 \pm 0.31^{\mathrm{a}}$ & $5.41 \pm 0.25^{\mathrm{a}}$ & $7.26 \pm 0.61^{\mathrm{b}}$ \\
59-87 dph & $10.66 \pm 0.34^{\mathrm{a}}$ & $12.28 \pm 0.29^{\mathrm{b}}$ & $15.57 \pm 0.53^{\mathrm{c}}$ \\
87-115 dph & $14.20 \pm 0.49^{\mathrm{a}}$ & $14.89 \pm 0.79^{\mathrm{a}}$ & $18.36 \pm 0.67^{\mathrm{b}}$ \\
Mortality rate (\%) & & & \\
31-59 dph & $46.67 \pm 10.35^{\mathrm{a}}$ & $36.89 \pm 2.78^{\mathrm{a}}$ & $40.00 \pm 9.26^{\mathrm{a}}$ \\
$59-87$ dph & $4.44 \pm 3.01^{\mathrm{a}}$ & $5.11 \pm 1.68^{\mathrm{a}}$ & $1.11 \pm 0.38^{\mathrm{a}}$ \\
87-115 dph & $0.22 \pm 0.38^{\mathrm{a}}$ & $1.78 \pm 0.77^{\mathrm{b}}$ & $0.44 \pm 0.38^{\mathrm{ab}}$ \\
31-115 dph (total) & $51.33 \pm 8.82^{\mathrm{a}}$ & $43.78 \pm 3.79^{\mathrm{a}}$ & $41.56 \pm 9.48^{\mathrm{a}}$ \\
Growth heterogeneity & & & \\
31-59 dph & $1.66 \pm 0.45^{\mathrm{b}}$ & $0.95 \pm 0.24^{\mathrm{ab}}$ & $0.82 \pm 0.25^{\mathrm{a}}$ \\
59-87 dph & $1.26 \pm 0.18^{\mathrm{a}}$ & $1.07 \pm 0.32^{\mathrm{a}}$ & $1.47 \pm 0.64^{\mathrm{a}}$ \\
$87-115$ dph & $1.22 \pm 0.16^{\mathrm{a}}$ & $0.85 \pm 0.22^{\mathrm{a}}$ & $1.30 \pm 0.33^{\mathrm{a}}$ \\
31-115 dph (total) & $2.47 \pm 0.28^{\mathrm{b}}$ & $0.81 \pm 0.20^{\mathrm{a}}$ & $1.42 \pm 0.54^{\mathrm{a}}$ \\
Cannibalism rate (\%) & & & \\
31-115 dph (total) & $26.44 \pm 5.55^{\mathrm{a}}$ & $28.22 \pm 5.00^{\mathrm{a}}$ & $28.89 \pm 0.77^{\mathrm{a}}$ \\
\hline
\end{tabular}

Growth heterogeneity differed significantly between SK and PL groups from 31 to $59 \mathrm{dph}$ ), with the PL population exhibiting the lowest GH (Table 2). However, no significant difference in GH was detected at later sampling points at $87 \mathrm{dph}$ and $115 \mathrm{dph}$.

Cannibalism was detected in all groups. The cannibalism rate was not significantly different in all groups (Table 2).

\subsection{Genetic differentiation among fish populations}

Sequencing data was obtained from 39 perch of the three populations (Table S1). The data matrix for D-loop (350 bp), 16S (541 bp), and COI (641 bp) contained four, five, and four unique haplotypes, respectively. The CytB (399 bp) data matrix was not polymorphic and presented only one previously reported haplotype (accession number KC819836) (Haponski and Stepien, 2013). The information of haplotype distribution is presented in Fig. 1.

The aligned sequences of the concatenated matrix (1931 bp) from 39 European perch exhibited 16 variable sites, defining 12 unique haplotypes with the two most common being H3, shared by 16 specimens recorded from SL, CZ, as well as H4 in 9 specimens from PL and SK (Fig. 1). The coefficient of genetic differentiation diversity among populations was $0.365(P<0.01)$. The concatenated matrix was characterized by high haplotype diversity $\left(\mathrm{H}_{\mathrm{d}}=0.780\right)$. AMOVA results demonstrated $22.84 \%$ of the genetic variation to be among populations and $77.16 \%$ of the genetic variation within populations.

The $\mathrm{F}_{\mathrm{ST}}$ value was 0.228 (AMOVA, $P<.01$ ), indicating significant population genetic structure. Pairwise $\mathrm{F}_{\mathrm{ST}}$ indicated strong differentiation of the PL population from the other populations (Table 3). The SK and $\mathrm{CZ}$ were weakly differentiated with low $\mathrm{F}_{\mathrm{ST}}$ values and no significant differentiation in AMOVA.

\section{Discussion}

\subsection{Geographic variation in aquaculture performance}

The aquaculture performance of the three studied fish populations suggests differences in potential for fish farming (Table 2). Populations differed in SGR, growth heterogeneity, traits currently impacting

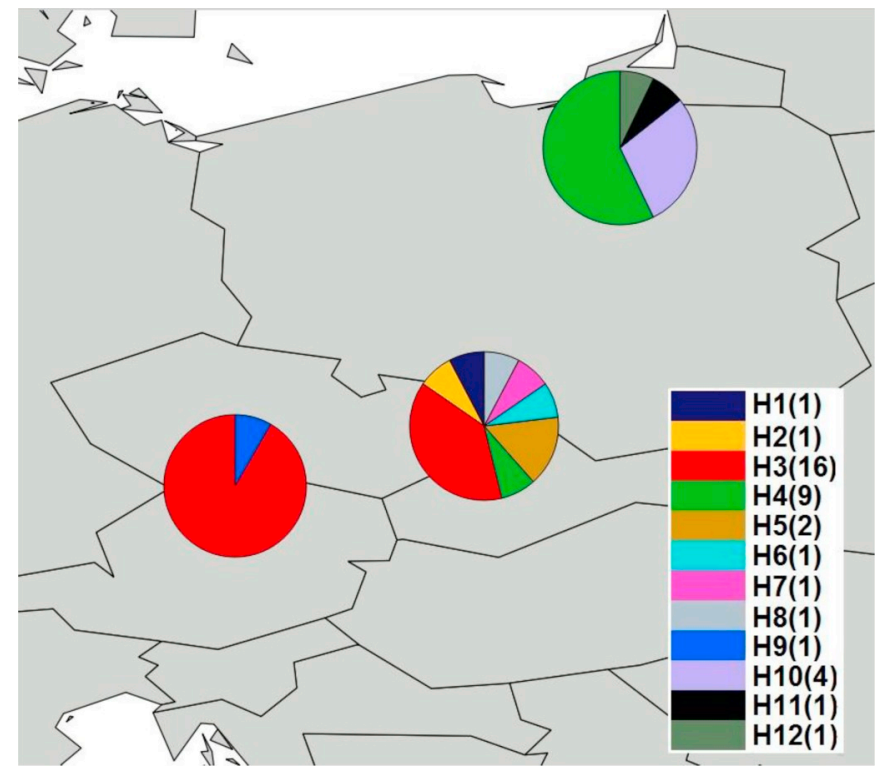

Fig. 1. Sampling areas and haplotype distribution of European perch populations. Different colours indicate different haplotypes. Numbers in brackets indicate the number of specimens sharing the haplotype.

Table 3

Pairwise $\mathrm{F}_{\mathrm{ST}}$ values from the mitochondrial dataset of European perch populations. $\mathrm{SK}=$ Slovakia, $\mathrm{CZ}=$ Czech Republic, $\mathrm{PL}=$ Poland.

\begin{tabular}{lll}
\hline & SK & CZ \\
\hline SK & & \\
CZ & 0.048 & \\
PL & $\mathbf{0 . 2 2 4}$ & $\mathbf{0 . 3 9 4}$ \\
\hline
\end{tabular}

Significant values in bold, $P=.01$.

European perch culture (Kestemont et al., 2015). Such populationspecific aquaculture performance has been reported in European perch from other geographic areas (Mandiki et al., 2004; Pimakhin and Žák, 2014). Therefore, consideration of differences among allopatric populations is important for the establishment or enhancement of European perch broodstock, as has been the case with other fish species (Rosenau and McPhail, 1987; Brown, 1994; Conover et al., 1997; Brown et al., 1998). Further comparative studies of other European perch populations are required to allow identifying the population(s) best suited to aquaculture.

\subsection{Sources of geographic variation in aquaculture performance}

Knowledge of the source of aquaculture performance differences among fish populations is critical to fish farming. However, establishing the origin of variation among allopatric fish populations is not straightforward. Differences can be explained by genetic differentiation (Avise, 2000) or phenotypic plasticity (DeWitt and Scheiner, 2004; Bergek and Björklund, 2009).

Past demographic events such as population movements triggered by climate cycles (Bernatchez and Wilson, 1998) and former/current geographic barriers (Bergek and Björklund, 2009) are important factors shaping within-species genetic differentiation. These factors can lead to a decrease or interruption of gene flow among allopatric conspecifics that fosters local genetic specificity through processes including genetic drift (Avise, 2000). Isolated gene pools may occur with diverse habitats, eco-climatic conditions, population densities, or food availability producing variation in selective pressure (Mayr, 1963). In this scenario, phenotypic variation can result as a consequence of genetic adaptations to the local environment (Losos and Ricklefs, 2009), for instance, to 
abiotic factors (temperature, levels of dissolved oxygen, ammonia, nitrites, salinity, photoperiod, food availability, and quality) as well as biotic factors (degree of competition, predation, and population density) (Hansson, 1984; Przybylski, 1996; Pierce et al., 2003).

Our study revealed genetic differences among specimens inhabiting different areas, especially with respect to the PL group vs. other populations (Table 2). The genetic differentiation is in agreement with Nesb $\emptyset$ et al. (1999). The results obtained in the PL population compared to the other groups conforms to the hypothesis that genetically different populations are likely to display variation in characteristics affecting their potential for aquaculture. However, we also observed variation in aquaculture performance among fish of genetically similar populations. This could be explained by an underestimation of the genetic variation based on analysis of only four mitochondrial markers. Phenotypically distinct organisms are not always characterized by large genetic differences (Ferguson, 2002; Salvato et al., 2002; Rheindt et al., 2011), making quantification of genetic differentiation challenging without further analyses of nuclear genes or of the entire genome. Alternatively, differences in any morphological, physiological, or behavioural trait among non-genetically similar fish populations could be a consequence of phenotypic plasticity (DeWitt and Scheiner, 2004).

Phenotypic plasticity is a ubiquitous phenomenon in living organisms in response to environmental conditions (DeWitt and Scheiner, 2004). It is predicted that high gene flow in an allopatric gene pool as suggested among CZ and SK populations by AMOVA, should favour the development and maintenance of phenotypic plasticity over local genetically-based adaptations (Crispo, 2008; Bergek and Björklund, 2009). Applying similar environmental conditions to different fish populations through transplant experiments, as in our study, minimizes potential effects of phenotypic plasticity on the studied traits and suggests a genetic basis for the variation (West-Eberhard, 2003; Rosburg, 2017). We collected specimens at the egg stage to rule out a potential phenotypic plasticity effect. Alteration in phenotype as a response to environmental cues can occur during development and extend through all or part of the life of an organism (Fusco and Minelli, 2010; Wiens et al., 2014). Ruling out a potential phenotypic plasticity effect would require breeding sequential generations of desired strains under similar conditions, requiring long term transplant experiments, which may be costly and time-consuming.

\subsection{Potential limitations}

In addition to genetic or phenotypic plasticity as a source of the observed differences in aquaculture performance, we cannot exclude possible sampling bias. First, we did not conduct an initial assessment of pathogens in the specimens. Although mortality rates were similar among populations, pathogens may have affected performance of a population without leading to increased mortality.

Second, the wild egg ribbons were collected from unknown broodstock. Therefore, observed interpopulational divergences could be differences between genetic pool families that can affect the offspring husbandry performances. However, we argue that our sampling design minimizes such an effect. We minimize the risk of studying individuals with a high degree of kinship by mixing larvae from different egg ribbons (i.e. one ribbon is laid by on female) for each population. Third, environmental conditions such as diet, parasites, and water temperature experienced by the parent fish may be important in shaping offspring phenotype (Mousseau and Fox, 1998): Past environmental circumstances may contribute as much as current conditions to performance (Devevey et al., 2010). Such a transgenerational effect is not determined by the offspring's genome but instead by the environmental experience of its parents (Youngson and Whitelaw, 2008). Therefore, fish obtained from parents with high condition through a resource-rich/pathogen-low environment may acquire the parent condition and thus perform better under any environmental conditions than does offspring of poor quality parents (Valtonen et al., 2012).
Performance of European perch larvae can be impacted by maternal size (Olin et al., 2012). Since we have no information about the parents of the sampled egg ribbons, we cannot exclude such a transgenerational or maternal effect.

\section{Conclusion}

According to our result, we suggest that aquaculture performance differs among allopatric populations, as previously stated for other fish species. Therefore, quantification of geographic variation in key traits could have potential for overcoming current issues in European perch aquaculture. The differences were mainly observed between genetically differentiated populations but lower divergences where recorded between genetically undifferentiated populations. These latter differences could be a consequence of different health status, pre-collection environment, or transgenerational effects. Further studies are needed to assess the importance of these factors in geographic differentiation of aquaculture performance.

\section{Funding}

This study was supported by the Ministry of Education, Youth and Sports of the Czech Republic - projects CENAKVA (No. CZ.1.05/2.1.00/ 01.0024), CENAKVA II (No. LO1205 under the NPU I program), GAJU project (No. 060/2016/Z) and NAZV Kouřil (No. QJ 1510117). LT is supported by a grant from the Ministère de l'Enseignement Supérieur et de la Recherche.

\section{Author contributions}

JK, VS, RG, and VT conceived the original idea. JK, VS, and TV carried out the sampling and transport of egg ribbons. TV and RG contributed to the rearing process. TL, LT, MB, and VT contributed to laboratory genetic analyses. TL and MR performed statistical analyses. TV, RG, LT, and TL led the writing. All authors discussed the results and contributed to the final manuscript, revising it critically for content.

\section{Acknowledgements}

We are very grateful to Ivana Samková and Pavel Šablatura with Jan Matoušek for their excellent technical assistance during the genetic evaluation and care of fish during the rearing period. We also would like to thank all providers of egg ribbons for their assistance in sampling: Dariusz Kucharczyk (Poland), Kamila Rošková (Czech Republic), Davide Menozzi (Italy), Pal’o Král and Peter Štofko (Slovakia).

\section{Appendix A. Supplementary data}

Supplementary data to this article can be found online at https:// doi.org/10.1016/j.aquaculture.2018.12.071.

\section{References}

Avise, J.C., 2000. Phylogeography: the History and Formation of Species. Harvard University Press, London, England, MA.

Baras, E., Kestemont, P., Mélard, C., 2003. Effect of stocking density on the dynamics of cannibalism in sibling larvae of Perca fluviatilis under controlled conditions. Aquaculture 219, 241-255. https://doi.org/10.1016/S0044-8486(02)00349-6.

Bergek, S., Björklund, M., 2009. Genetic and morphological divergence reveals local subdivision of perch (Perca fluviatilis L.). Biol. J. Linn. Soc. 96, 746-758. https://doi. org/10.1111/j.1095-8312.2008.01149.x.

Bernatchez, L., Wilson, C.C., 1998. Comparative phylogeography of Nearctic and Palearctic fishes fishes. Mol. Ecol. 7, 431-452. https://doi.org/10.1046/j.1365-294x. 1998.00319.x.

Brabrand, A., 1995. Intra-cohort cannibalism among larval stages of perch (Perca fluviatilis). Ecol. Freshw. Fish 4, 70-76. https://doi.org/10.1111/j.1600-0633.1995. tb00119.x.

Brown, J.J., 1994. Variation in Growth Rate of Larvae Striped Bass Morone saxatilis Stocks From Different Latitudes. M.S. thesis. State University of New York, Stony Brook. 
Brown, J.J., Ehtisman, A., Conover, D.O., 1998. Variation in larval growth rate among striped bass stocks from different latitudes. Trans. Am. Fish. Soc. 127, 598-610.

Conover, D.O., Brown, J.J., Ehtisham, A., 1997. Countergradient variation in growth of young striped bass (Morone saxatilis) from different latitudes 1 . Can. J. Fish. Aquat. Sci. 54, 2401-2409. https://doi.org/10.1139/f97-147.

Crispo, E., 2008. Modifying effects of phenotypic plasticity on interactions among natural selection, adaptation and gene flow. J. Evol. Biol. 21, 1460-1469. https://doi.org/10. 1111/j.1420-9101.2008.01592.x.

Cuvier-Péres, A., Kestemont, P., 2001. Development of some digestive enzymes in Eurasian perch larvae Perca fluviatilis. Fish Physiol. Biochem. 24, 279-285. https:// doi.org/10.1023/A:1015033300526.

Devevey, G., Bize, P., Fournier, S., Person, E., Christe, P., 2010. Testing the predictive adaptive response in a host-parasite system. Funct. Ecol. 24, 178-185. https://doi. org/10.1111/j.1365-2435.2009.01609.x.

DeWitt, T.J., Scheiner, S.M., 2004. Phenotypic variation from single genotypes: a primer. In: DeWitt, T.J., Scheiner, S.M. (Eds.), Phenotypic Plasticity: Functional and Conceptual Approaches. Oxford University Press, New York, pp. 1-9.

Excoffier, L., Laval, G., Schneider, S., 2005. Arlequin (version 3.0): an integrated software package for population genetics data analysis. Evol. Bioinforma. 1, 47-50. https:// doi.org/10.1177/117693430500100003.

FAO, 2016. The State of World Fisheries and Aquaculture 2016. Contributing to Food Security and Nutrition for all. Food and Agriculture Organization of the United Nations, Rome, Italy. http://www.fao.org/publications/sofia/2016/en/.

Ferguson, J.W.H., 2002. On the use of genetic divergence for identifying species. Biol. J. Linnean Soc. 75, 509-516. https://doi.org/10.1046/j.1095-8312.2002.00042.x.

Fiogbé, E.D., Kestemont, P., 2003. Optimum daily ration for Eurasian perch Perca fluviatilis L. reared at its optimum growing temperature. Aquaculture 216, 243-252. https://doi.org/10.1016/S0044-8486(02)00409-X.

Fontaine, P., Legendre, M., Vandeputte, M., Fostier, A., 2009. Domestication de nouvelles espèces de poissons peut-elle participer au développement durable de la pisciculture. Cahiers d'Agriculture 18, 119-124. https://doi.org/10.1684/agr.2009.0293.

Fusco, G., Minelli, A., 2010. Phenotypic plasticity in development and evolution: facts and concepts. Introduction. Philos. Trans. R. Soc. Lond. B Biol. Sci. 365, 547-556.

Garibaldi, L.A., Bartley, D., 1998. The database on introductions of aquatic species (DIAS): the web site. FAO Aquacult. Newsl. 20, 20-24.

Godoy, M.G., Aedo, A., Kibenge, M.J., Groman, D.B., Yason, C.V., Grothusen, H., Lisperguer, A., Calbucura, M., Avendano, F., Imilan, M., Jarpa, M., Kibenge, F.S., 2008. First detection, isolation and molecular characterization of infectious salmon anaemia virus associated with clinical disease in farmed Atlantic salmon (Salmo salar) in Chile. BMC Vet. Res. 4, 28. https://doi.org/10.1186/1746-6148-4-28.

Hansson, S., 1984. Competition as a factor regulating the geographical distribution of fish species in a Baltic archipelago: a neutral model analysis. J. Biogeogr. 11, 367-381. https://doi.org/10.2307/2844802.

Haponski, A.E., Stepien, C.A., 2013. Phylogenetic and biogeographical relationships of the Sander pikeperches (Percidae: Perciformes): patterns across North America and Eurasia. Biol. J. Linnean Soc. 110, 156-179. https://doi.org/10.1111/bij.12114.

Irwin, D.M., Kocher, T.D., Wilson, A.C., 1991. Evolution of the cytochrome b gene of mammals. J. Mol. Evol. 32, 128-144.

Jentoft, S., ØXnevad, S., Aastveit, A.H., Andersen, Ø., 2006. Effects of tank wall color and up-welling water flow on growth and survival of Eurasian perch larvae (Perca fluviatilis). J. World Aquacult. Soc. 37, 313-317. https://doi.org/10.1111/j.1749-7345. 2006.00042.x.

Katoh, K., Rozewicki, J., Yamada, K.D., 2017. MAFFT online service: multiple sequence alignment, interactive sequence choice and visualization. Brief. Bioinform. https:// doi.org/10.1093/bib/bbx108. (bbx108).

Kearse, M., Moir, R., Wilson, A., Stones-Havas, S., Cheung, M., Sturrock, S., Buxton, S., Cooper, A., Markowitz, S., Duran, C., Thierer, T., Ashton, B., Meintjes, P., Drummond, A., 2012. Geneious basic: an integrated and extendable desktop software platform for the organization and analysis of sequence data. Bioinformatics 28, 1647-1649. https://doi.org/10.1093/bioinformatics/bts199.

Kestemont, P., Mélard, C., 2000. Aquaculture. In: Graig, I.F. (Ed.), Percid Fishes. Systematics, Ecology and Exloitation. Blackwell Science, Oxford, pp. 191-224.

Kestemont, P., Mélard, C., Fiogbe, E., Vlavonou, R., Masson, G., 1996. Nutritional and animal husbandry aspects of rearing early life stages of Eurasian perch Perca fluvia tilis. J. Appl. Ichthyol. 12, 157-165. https://doi.org/10.1111/j.1439-0426.1996. tb00082.x.

Kestemont, P., Jourdan, S., Houbart, M., Mélard, C., Paspatis, M., Fontaine, P., Cuvier, A., Kentouri, M., Baras, E., 2003. Size heterogeneity, cannibalism and competition in cultured predatory fish larvae: biotic and abiotic influences. Aquaculture 227, 333-356. https://doi.org/10.1016/S0044-8486(03)00513-1.

Kestemont, P., Mélard, C., Held, J., Dabrowski, K., 2015. Culture methods of Eurasian perch and Yellow perch early life stages. In: Kestemont, P., Dabrowski, K., Summerfelt, R.C. (Eds.), Biology and Culture of Percid Fishes. Springer, pp. 265-293.

Křrištan, J., Stejskal, V., Policar, T., 2012. Comparison of reproduction characteristics and broodstock mortality in farmed and wild Eurasian perch (Perca fluviatilis L.) females during spawning season under controlled conditions. Turk. J. Fish. Aquat. Sci. 12, 191-197. https://doi.org/10.4194/1303-2712-v12_2_01.

Lecocq, T., Dellicour, S., Michez, D., Lhomme, P., Vanderplanck, M., Valterová, I., Rasplus, J.-Y., Rasmont, P., 2013. Scent of a break-up: phylogeography and reproductive trait divergences in the red-tailed bumblebee (Bombus lapidarius). BMC Evol. Biol. 13, 263. https://doi.org/10.1186/1471-2148-13-263.

Ljubobratović, U., Kucska, B., Feledi, T., Poleksić, V., Marković, Z., Lenhardt, M., Peteri, A., Kumar, S., Rónyai, A., 2015. Effect of weaning strategies on growth and survival of Pikeperch, Sander lucioperca, larvae. Turk. J. Fish. Aquat. Sci. 15, 325-331. https://doi.org/10.4194/1303-2712-v15_2_15.

Ljunggren, L., Staffan, F., Falk, S., Linden, B., Mendes, J., 2003. Weaning of juvenile pikeperch, Stizostedion lucioperca L., and perch, Perca fluviatilis L., to formulated feed. Aquac. Res. 34, 281-287. https://doi.org/10.1046/j.1365-2109.2003.00805.x.

Losos, J.B., Ricklefs, R.E., 2009. Adaptation and diversification on islands. Nature 457, 830-836. https://doi.org/10.1038/nature07893.

Maddison, W.P., Maddison, D.R., 2015. Mesquite: A Modular System for Evolutionary Analysis (Version 3.04). https://mesquiteproject.org.

Mandiki, S., Blanchard, G., Mélard, C., Koskela, J., Kucharczyk, D., Fontaine, P., Kestemont, P., 2004. Effects of geographic origin on growth and food intake in Eurasian perch (Perca fluviatilis L.) juveniles under intensive culture conditions. Aquaculture 229, 117-128. https://doi.org/10.1016/S0044-8486(03)00359-4.

Mayr, E., 1963. Animal Species and Evolution. Harvard University Press, Cambridge, MA.

Mélard, C., Kestemont, P., Grignard, J.C., 1996. Intensive culture of juvenile and adult Eurasian perch ( $P$. fluuiatilis): effect of major biotic and abiotic factors on growth. J. Appl. Ichthyol. 12, 175-180. https://doi.org/10.1111/j.1439-0426.1996.tb00085.x.

Mousseau, T., Fox, C.W., 1998. The adaptive significance of maternal effects. Trends Ecol. Evol. 13, 403-407. https://doi.org/10.1016/S0169-5347(98)01472-4.

Nesbø, C.L., Arab, M.O., Jakobsen, K.S., 1998. Heteroplasmy, length and sequence variation in the mtDNA control regions of three percid fish species (Perca fluviatilis, Acerina cernua, Stizostedion lucioperca). Genetics 148, 1907-1919.

Nesbø, C.L., Fossheim, T., Vøllestad, L., Jakobsen, K., 1999. Genetic divergence and phylogeographic relationships among European perch (Perca fluviatilis) populations reflect glacial refugia and postglacial colonization. Mol. Ecol. 8, 1387-1404. https:// doi.org/10.1046/j.1365-294x.1999.00699.x.

Olin, M., Jutila, J., Lehtonen, H., Vinni, M., Ruuhijärvi, J., Estlander, S., Rask, M., Kuparinen, A., Lappalainen, J., 2012. Importance of maternal size on the reproductive success of perch, Perca fluviatilis, in small forest lakes: implications for fisheries management. Fish. Manag. Ecol. 19, 363-374. https://doi.org/10.1111/j. 1365-2400.2012.00845.x.

Palumbi, S.R., 1996. Nucleic acids II: the polymerase chain reaction. In: Hillis, D.M., Moritz, C., Mable, B.K. (Eds.), Molecular systematics Sinauer Associates, Inc, Sunderland, MA, pp. 205-247.

Pierce, R.B., Tomcko, C.M., Margenau, T.L., 2003. Density dependence in growth and size structure of northern pike populations. N. Am. J. Fish. Manag. 23, 331-339. https:// doi.org/10.1577/1548-8675(2003)023\%3C0331:DDIGAS\%3E2.0.CO;2.

Pigliucci, M., Murren, C.J., Schlichting, C.D., 2006. Phenotypic plasticity and evolution by genetic assimilation. J. Exp. Biol. 209, 2362-2367. https://doi.org/10.1242/jeb. 02070.

Pimakhin, A., Žák, J., 2014. Effect of body size on swim bladder inflation in intensively cultured Eurasian perch larvae from different locations. World Aquacult. 45, 37-41.

Policar, T., Toner, D., Alavi, S.M.H., Linhart, O., 2008. Reproduction and spawning. In: Toner, D., Rougeot, C. (Eds.), Farming of Eurasian Perch. Aquaculture Development Division. Borde Iascaigh Mhara, Dublin, pp. 22-29.

Przybylski, M., 1996. The diet feeding pattern of bitterling, Rhodeus sericeus amarus [Bloch] in the Wieprz-Krzna Canal, Poland. Pol. Arch. Hydrobiol. 43, 203-212.

R Development Core Team, 2018. R: A Language and Environment for Statistical Computing. R Foundation for Statistical Computing, Vienna. https://www.R-project. org.

Rheindt, F.E., Székely, T., Edwards, S.V., Lee, P.L.M., Burke, T., Kennerley, P.R., Bakewell, D.N., Alrashidi, M., Kosztolányi, A., Weston, M.A., Liu, W.-T., Lei, W.-P., Shigeta, Y., Javed, S., Zefania, S., Küpper, C., 2011. Conflict between genetic and phenotypic differentiation: the evolutionary history of a 'Lost and Rediscovered' Shorebird. PLoS One 6, e26995. https://doi.org/10.1371/journal.pone.0026995.

Rosauer, D.R., Biga, P.R., Lindell, S.R., Binkowski, F.P., Shepherd, B.S., Palmquist, D.E., Simchick, C.A., Goetz, F.W., 2011. Development of yellow perch (Perca flavescens) broodstocks: initial characterization of growth and quality traits following grow-out of different stocks. Aquaculture 317, 58-66. https://doi.org/10.1016/j.aquaculture. 2011.03.037.

Rosburg, A.J., 2017. Growth POTENTIAL and Genetic Diversity of Yellow Perch in South Dakota (Thesis and Dissertations). 2163. pp. 1-52. https://openprairie.sdstate.edu/ etd/2163.

Rosenau, M.L., McPhail, J.D., 1987. Inherited differences in agonistic behavior between two populations of coho salmon. Trans. Am. Fish. Soc. 116, 646-654. https://doi. org/10.1577/1548-8659(1987)116\%3C646:IDIABB\%3E2.0.CO;2.

Rougeot, C., Mélard, C., 2008. Genetic improvement for growth. In: Toner, D., Rougeot, C. (Eds.), Farming of Eurasian Perch. Aquaculture Development Division. Borde Iascaigh Mhara, Dublin, pp. 42-51.

Salvato, P., Battisti, A., Concato, S., Masutti, L., Patarnello, T., Zane, L., 2002. Genetic differentiation in the winter pine processionary moth (Thaumetopoea pityocampa wilkinsoni complex), inferred by AFLP and mitochondrial DNA markers. Mol. Ecol. 11, 2435-2444. https://doi.org/10.1046/j.1365-294X.2002.01631.x.

Stepien, C.A., Haponski, A.E., 2015. Taxonomy, distribution, and evolution of the percidae. In: Kestemont, P., Dabrowski, K., Summerfelt, R.C. (Eds.), Biology and Culture of Percid Fishes. Springer Netherlands, Dordrecht, pp. 3-16.

Tamazouzt, L., Chatain, B., Fontaine, P., 2000. Tank wall colour and light level affect growth and survival of Eurasian perch larvae (Perca fluviatilis L.). Aquaculture 182, 85-90. https://doi.org/10.1016/S0044-8486(99)00244-6.

Teletchea, F., Fontaine, P., 2014. Levels of domestication in fish: implications for the sustainable future of aquaculture. Fish Fish. 15, 181-195. https://doi.org/10.1111/ faf.12006.

Toner, D., 2015. The market for Eurasian perch. In: Kestemont, P., Dąbrowski, K., Summerfelt, R.C. (Eds.), Biology and Culture of Percid Fishes. Springer Netherlands, Dordrecht, pp. 865-879.

Valtonen, T.M., Kangassalo, K., Pölkki, M., Rantala, M.J., 2012. Transgenerational effects of parental larval diet on offspring development time, adult body size and pathogen resistance in Drosophila melanogaster. PLoS One 7, e31611. https://doi.org/10.1371/ journal.pone.0031611. 
Vrijenhoek, R., 1994. DNA primers for amplification of mitocondrial cytocrome C oxidase subunit I from diverse metazoan invertebrates. Mol. Mar. Biol. Biotechnol. 3, 294-299.

West-Eberhard, M.J., 2003. Developmental Plasticity and Evolution, 1st ed. Oxford University Press.

Wiens, K.E., Crispo, E., Chapman, L.J., 2014. Phenotypic plasticity is maintained despite geographical isolation in an African cichlid fish, Pseudocrenilabrus multicolor. Itegr. Zool. 9, 85-96. https://doi.org/10.1111/1749-4877.12029.

Youngson, N.A., Whitelaw, E., 2008. Transgenerational epigenetic effects. Annu. Rev. Genomics Hum. Genet. 9, 233-257. https://doi.org/10.1146/annurev.genom.9.
081307.164445.

Żarski, D., Palińska, K., Targońska, K., Bokor, Z., Kotrik, L., Krejszeff, S., Kupren, K. Horváth, Á., Urbányi, B., Kucharczyk, D., 2011. Oocyte quality indicators in Eurasian perch, Perca fluviatilis L., during reproduction under controlled conditions. Aquaculture 313, 84-91. https://doi.org/10.1016/j.aquaculture.2011.01.032.

Żarski, D., Horváth, Á., Bernáth, G., Krejszeff, S., Radóczi, J., Palińska-Żarska, K., Bokor, Z., Kupren, K., Urbányi, B., 2017. Incubation and hatching. In: Żarski, D. (Ed.),

Controlled Reproduction of Wild Eurasian Perch: A Hatchery Manual. Springer, pp.

81-88. 